\title{
Hydrogen Sulfide and Carbon Monoxide Tolerance in Bacteria
}

\author{
Sofia S. Mendes ${ }^{\dagger}$, Vanessa Miranda ${ }^{+} \mathbb{D}$ and Lígia M. Saraiva ${ }^{*}+t^{\mathbb{D}}$ \\ Instituto de Tecnologia Química e Biológica António Xavier, Universidade Nova de Lisboa, \\ Avenida da República, 2780-157 Oeiras, Portugal; ass.mendes@itqb.unl.pt (S.S.M.); vmiranda@itqb.unl.pt (V.M.) \\ * Correspondence: lst@itqb.unl.pt \\ t These authors contributed equally to this work.
}

Citation: Mendes, S.S.; Miranda, V.; Saraiva, L.M. Hydrogen Sulfide and Carbon Monoxide Tolerance in Bacteria. Antioxidants 2021, 10, 729. https: / / doi.org/10.3390/ antiox10050729

Academic Editor: Daniele Mancard

Received: 7 April 2021

Accepted: 3 May 2021

Published: 5 May 2021

Publisher's Note: MDPI stays neutral with regard to jurisdictional claims in published maps and institutional affiliations.

\begin{abstract}
Hydrogen sulfide and carbon monoxide share the ability to be beneficial or harmful molecules depending on the concentrations to which organisms are exposed. Interestingly, humans and some bacteria produce small amounts of these compounds. Since several publications have summarized the recent knowledge of its effects in humans, here we have chosen to focus on the role of $\mathrm{H}_{2} \mathrm{~S}$ and $\mathrm{CO}$ on microbial physiology. We briefly review the current knowledge on how bacteria produce and use $\mathrm{H}_{2} \mathrm{~S}$ and $\mathrm{CO}$. We address their potential antimicrobial properties when used at higher concentrations, and describe how microbial systems detect and survive toxic levels of $\mathrm{H}_{2} \mathrm{~S}$ and $\mathrm{CO}$. Finally, we highlight their antimicrobial properties against human pathogens when endogenously produced by the host and when released by external chemical donors.
\end{abstract}

Keywords: bacteria; hydrogen sulfide; carbon monoxide; CORMs

\section{Introduction}

Hydrogen sulfide $\left(\mathrm{H}_{2} \mathrm{~S}\right)$ and carbon monoxide $(\mathrm{CO})$ are small molecules that are historically related with environmental industrial pollution. However, the two compounds have long been recognized as also being produced by mammalian and bacterial cells in low amounts that mediate important physiological processes [1,2].

$\mathrm{H}_{2} \mathrm{~S}$ diffuses through cell membranes and inside cells, at physiological $\mathrm{pH}$, is mainly present in the deprotonated conjugate base form of hydrosulfide anion (HS ${ }^{-}$). Here, we will use sulfide to refer collectively to the $\mathrm{H}_{2} \mathrm{~S}$ and $\mathrm{HS}^{-}$forms. In organisms, $\mathrm{H}_{2} \mathrm{~S}$ is the product of enzymes of the trans-sulfuration pathway. Mammals express three $\mathrm{H}_{2} \mathrm{~S}$ generating enzymes: cystathionine $\beta$-synthase (CBS), cystathionine $\gamma$-lyase (CSE), and 3-mercaptopyruvate sulfurtransferase (3MST or MPST). CBS and CSE form $\mathrm{H}_{2} \mathrm{~S}$ predominantly from L-cysteine, while the $3 \mathrm{MST}$ enzyme generates $\mathrm{H}_{2} \mathrm{~S}$ via the synthesis of the intermediate 3-mercaptopyruvate, which is produced by cysteine aminotransferase [3-5].

Carbon monoxide present in the environment is a product of fuel combustion. Mammals also produce $\mathrm{CO}$ endogenously through heme oxygenase $(\mathrm{HO})$ enzymes that degrade heme releasing $\mathrm{CO}$, biliverdin, which is reduced to bilirubin and ferrous iron, which is scavenged by ferritin. Humans express three $\mathrm{HO}$ isoforms: $\mathrm{HO}-1$, which is inducible by heme and oxidative stress; HO-2, which is constitutively produced; and HO-3, which is a poor heme degrading catalyst and is most likely a regulator of proteins, such as HO-1. The products of HO-catalyzed reactions are considered to play a relevant role in oxidative stress protection of cells [6]. CO has potential for therapeutic applications through three modes of delivery: induction of genes encoding heme oxygenases; inhalation of gaseous CO; and use of CO-releasing molecules (CORMs) [7]. CORMs exhibit vasodilatory, regulation of mitochondrial respiration, anti-inflammatory, anti-apoptotic, anti-ischemic, and cardioprotective properties $[8,9]$.

Prokaryotes also utilize and generate $\mathrm{H}_{2} \mathrm{~S}$ and $\mathrm{CO}$, and their important role may be inferred from the widespread presence in the microbial genomes of putative orthologs, of at least one, of the eukaryotic $\mathrm{H}_{2} \mathrm{~S}$ and $\mathrm{CO}$ producing enzymes. At physiological $\mathrm{pH}$, 
the lifetimes of $\mathrm{H}_{2} \mathrm{~S}$ and $\mathrm{CO}$ are quite different: while $\mathrm{H}_{2} \mathrm{~S}$ has a reduced lifetime, the greater stability of $\mathrm{CO}$ allows it to have effects in sites distant from where it is produced. The beneficial or harmful effects of $\mathrm{H}_{2} \mathrm{~S}$ and $\mathrm{CO}$ depend mainly on their concentrations, but also on the organisms and environmental conditions. At high concentrations, both are toxic to mammals and microbes, and, more recently, their antimicrobial potentials have been explored. This review summarizes the current knowledge on the antimicrobial properties of $\mathrm{H}_{2} \mathrm{~S}$ and $\mathrm{CO}$ and the physiological adaptation of microbes when exposed to these stresses.

\section{Bacterial Responses to $\mathrm{H}_{2} \mathrm{~S}$}

In general, low concentrations of $\mathrm{H}_{2} \mathrm{~S}$ in the micromolar range are cytoprotective, but millimolar concentrations are cytotoxic to microbes, and some prokaryotes contain proteins for protection against $\mathrm{H}_{2} \mathrm{~S}$ efflux transporters [10-12].

High concentrations of sulfides hamper bacterial growth, as shown for Escherichia coli, Shewanella oneidensis, Aspergillus niger, Penicillium italicum, and Acinetobacter baumanni. In all these microorganisms, sulfide inhibits the activity of superoxide dismutase and catalase enzymes that are linked to cellular defenses against oxidative stress. Consequently, it causes an elevation of the intracellular reactive oxygen species (ROS) content and reduction of the glutathione levels [13-15]. In A. baumanni, NaHS (80-160 $\mu \mathrm{M})$ caused membrane depolarization and lowered the ATP levels [16]. In general, the toxicity of sulfide, besides being associated with oxidative damage via inhibition of antioxidant proteins, also results from DNA damage, lipid peroxidation, protein denaturation through disulfide disruption, and inactivation of redox centers in metalloenzymes due to its binding to the metals $[1,17,18]$.

In addition, toxic sulfur-containing compounds produced by bacteria contribute to antagonistic interactions with microbes occupying the same niche [19]. Proteus mirabilis, member of the Enterobacteriaceae family and a $\mathrm{H}_{2} \mathrm{~S}$ producer, exerts bactericidal effect over E. coli, Klebsiella pneumoniae and Morganella morganii in planktonic cells and mixed biofilms [20].

Several sulfide-specific transcription repressors, such as CstR, SqrR/BigR, FisR and CsoR have been identified [21-23] and, in E. coli, sulfide was also described to activate two major redox-responsive transcriptional regulators, namely SoxRS and OxyR [13] (Figure 1).

How bacteria respond to sulfide toxicity has been addressed by a limited number of works, which include transcriptomic and proteomic studies. Analysis of the transcriptome of A. baumanni when exposed to sulfide stress generated by $0.2 \mathrm{mM} \mathrm{Na}_{2} \mathrm{~S}$ [22], revealed the up-regulation of genes encoding persulfide dioxygenase (PDO1), sulfide:quinone oxidoreductase (SQR), a putative sulfite effluxer TauE, terminal ubiquinol oxidase of the cytochrome $b d$-type, an oxidase that is resistant to $\mathrm{H}_{2} \mathrm{~S}$ [24], a putative copper transport $\mathrm{OprC}$, ferritin-like gene products, flavohemoglobin/nitric oxide dioxygenase, and the [4Fe$4 \mathrm{~S}]$-containing nitric oxide-sensing transcriptional repressor (NsrR). Genes with reduced expression included those related to uptake of sulfur and derivatives, such as the $A B C$ transporters putatively involved in the uptake of sulfonate taurine and inorganic sulfate, and putative glutamate and aspartate transporters. Interestingly, only a few members of the OxyR regulon were modified, indicating that, in this pathogen, OxyR does not respond directly to sulfide, and suggesting that the responses to $\mathrm{Na}_{2} \mathrm{~S}$ and $\mathrm{H}_{2} \mathrm{O}_{2}$ stress differ significantly. Concerning the proteomic data [24], exposure of A. baumanni to sulfide increased the abundance of ROS-detoxification enzymes (heme-catalase, superoxide dismutase, alkyl hydroperoxidase, and universal stress proteins), metabolic enzymes (aconitase, isocitrate lyase, succinate semialdehyde dehydrogenase, and malate synthase), and proteins that respond to high-Fe and high-Cu levels, such as the periplasmic and cytoplasmic copper chaperones (CusF, CopZ), lipoprotein NlpE, and the iron storage ferritin FntA and bacterioferritin, of which corresponding genes were also seen induced in the transcriptome analysis. Furthermore, cells lacking the FisR regulator and that were exposed to $\mathrm{H}_{2} \mathrm{~S}$ showed elevated abundance of a ferric siderophore receptor protein, a glutathione-dependent disulfide bond oxidoreductase, and a nitrite/sulfite reductase. 


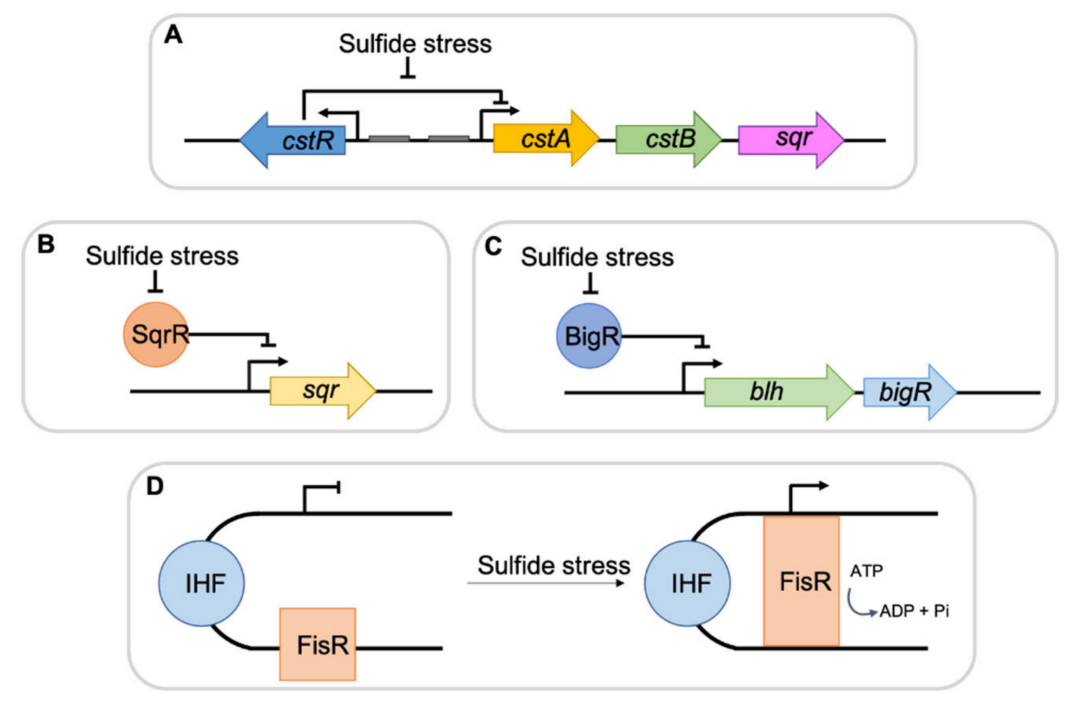

Figure 1. General scheme summarizing bacterial $\mathrm{H}_{2} \mathrm{~S}$ regulators. (A) CstR regulator binds to the upstream region of the cst genes repressing their expression. During sulfide stress, the DNA-binding affinity of the repressor decreases allowing for RNA polymerase binding and gene transcription. $(B, C)$ SqrR and BigR bind to promoter regions of $s q r, b l h$ and $b i g R$ genes, inhibiting transcription. In the presence of sulfide, the repression is lifted and genes expression occurs. (D) Under sulfide stress, FisR hydrolizes ATP to ADP plus free phosphate, resulting in RNA polymerase activation and increase in gene expression.

In Bacillus subtilis and Staphylococcus aureus, high amounts of sulfide repressed the transcription of cysteine synthase (cysK), cysM encoding CBS, and metB encoding CSE, which allow sulfur assimilation from thiol and homocysteine. Also repressed were the genes coding for methionine and cysteine $\mathrm{ABC}$ transporters, the operon for a sulfurtransferaselike protein, and a gene of a putative thiosulfate importer [25-27]. In S. aureus, exogenous sulfide induced the copper-sensing cst operon that is mediated by the sulfurtransferase repressor CstR. Cst includes proteins that mitigate sulfide toxicity, such as CstA and CstB, that are a multidomain sulfurtransferase and a non-heme Fe persulfide dioxygenase, respectively, and the SQR sulfide:quinone oxidoreductase that catalyzes the oxidation of sulfide to sulfane sulfur [28]. Consistent with the data, strains deleted in the genes of the cst operon $(\Delta c s t A, \Delta c s t B$, and $\Delta s q r)$ exhibited impaired growth in the presence of NaHS. Sulfide also modifies genes encoding enzymes and regulators involved in sugar $(g l p F$, marR, gapB, scrR, gntK, and gntR) and amino acid (putA) metabolisms [29]. The overall transcription pattern suggests that the $S$. aureus response to sulfide shares similarities with that under zinc limitation. For example, sulfide upregulates the zinc uptake repressor (Zur) regulon, represses zinc transporters and a zinc-binding lipoprotein. It induces genes for manganese transporters MntABC, that are controlled by the MntR repressor, and the $\mathrm{Co} / \mathrm{Ni}$ uptake system. Accordingly, sulfide decreases the intracellular Zn levels by approximately 10 -fold, causing only a small reduction of the intracellular $\mathrm{Cu} / \mathrm{Ni}$ levels, and no alteration in Mn/Fe levels [30].

\section{3. $\mathrm{H}_{2} \mathrm{~S}$ Producing Bacteria Confer Self-Protection against Oxidative Stress}

Bacteria can produce sulfide as by-product of its sulfur metabolism, e.g., the intestinal sulfate-reducing bacteria (SRB), and through cysteine desulfurases. In general, sulfide releasing bacteria support quite high concentrations of sulfide, as is the case of the SRB Desulfovibrio piger that grows in concentrations up to $4 \mathrm{mM}$ of sulfide [29]. However, the species that co-live in the gut environment, such as Lactobacillus spp., are affected in a way that varies among species. For example, sulfide is more toxic to L. pentosus, L. paracasei and L. reuteri than to L. fermentum and L. plantarum [30]. 
A large number of bacteria contain at least one ortholog of the eukaryotic $\mathrm{H}_{2} \mathrm{~S}$ producing enzymes, namely CBS, CSE or 3MST. In bacteria, as well as in eukaryotes and plants, endogenous sulfide production has been shown to be an important protective mechanism against oxidative stress and antibiotics. Specifically, inactivation of cbs, cse and 3mst genes in B. anthracis, Pseudomonas aeruginosa, S. aureus, E. coli and Mycobacterium tuberculosis resulted in strains less resistant to oxidative stress [11]. The ability of sulfide to mitigate oxidative stress stems apparently from various related factors. Sulfide promotes reduction of intracellular levels of cysteine, mediates sequestration of free iron reducing oxidative stress derived from the Fenton reaction, and induces genes encoding antioxidant enzymes. In these processes, the iron uptake regulator Fur appears to play a role, as shown for an E. coli strain $\Delta$ fur $\Delta 3$-mst mutant strain that had enhanced susceptibility to ROS. Consistent with these data, overexpression of 3-mst in E. coli $\Delta$ fur exhibited reduced DNA damage and decreased cell death. Furthermore, under oxidative stress, the up-regulation of E. coli $3-m s t$ is also triggered by the CysB regulator, that controls the transcription of several genes related to sulfur metabolism including the cysteine importer TcyP. Depletion of cysteine levels that occurs during oxidative stress activates the CysB regulon. The consequent induction of TcyP increases the influx of cysteine/cysteine thus resulting in elevated expression of 3-MST [31,32].

Nonetheless, more studies are required to allow for generalization of $\mathrm{H}_{2} \mathrm{~S}$ as a ROS protector molecule. For example, in $S$. oneidensis, the protective effect only occurred when $\mathrm{H}_{2} \mathrm{~S}$ was applied to cells prior to exposure to the oxidative stress effector $\left(\mathrm{H}_{2} \mathrm{O}_{2}\right)$, while the simultaneous addition of $\mathrm{H}_{2} \mathrm{~S}$ and $\mathrm{H}_{2} \mathrm{O}_{2}$ caused cell growth inhibition. The mechanism is still unclear, however authors have proposed that sulfide protection to Shewanella spp. could have physiological relevance as the bacterium resides in iron and sulfur rich niches [14].

\section{4. $\mathrm{H}_{2} \mathrm{~S}$ and Microbial Antibiotic Resistance}

A new mode of antibiotic resistance mediated by sulfide was reported in pathogenic bacteria that involves inhibition of the oxidative stress imposed by ROS-generating antibiotics. Several studies described that the genes encoding $\mathrm{H}_{2} \mathrm{~S}$-releasing enzymes, such as CBS and CSE, in B. anthracis, P. aeruginosa, S. aureus, and M. tuberculosis, or 3-MST in E. coli, contribute to tolerance to gentamicin, ampicillin and nalidixic acid [31,33].

In E. coli and M. tuberculosis, supplementation of cysteine or other small thiols also increased the resistance to gentamicin and rifampicin, respectively [34,35]. In E. coli, treatment of cells with ampicillin augmented the levels of cytochrome $b_{3}$ oxidase (cyoA) and lowered the expression of the cytochrome $b d$ quinol oxidase $(c y d B)$. However, preexposure of cells to sulfide reversed the expression pattern, and the more sulfide-resistant cytochrome $b d$ oxidase became prevalent. Moreover, sulfide protected cyo $A$ mutant from ampicillin toxicity but was ineffective in protecting the $c y d B$ mutant. Thus, the presence of sulfide forced E. coli to continue respiration catalyzed by cytochrome $b d$. Although less efficient, this alternative respiratory pathway based on a sulfide-resistant enzyme, which also appears to be able to act as catalase and quinol peroxidase, enhances the bacteria resistance to antibiotics [24,35].

Still, more recent studies have called into question the widely held notion that sulfide is a bacterial defense mechanism against antibiotics. In S. aureus, sulfide exacerbated the killing by antibiotics such as quinolones, and the sulfide-mediated protection was limited to aminoglycosides, such as gentamicin. Furthermore, the sulfide-induced tolerance to gentamicin was due to the decrease in gentamicin uptake and not to the reduction of oxidative stress [31].

In A. baumanni, which does not produce sulfide endogenously, co-treatment of antibioticsand NaHS potentiated the activity of ROS-producing antibiotics such as gentamicin, colistin, rifampicin and clarithromycin by several orders of magnitude. In this case, the effect of sulfide, which is opposite to what would have been expected from the results described above for $E$. coli, seems to be linked with the ability of $\mathrm{H}_{2} \mathrm{~S}$ alone to compromise 
bacterial cell redox homeostasis [16]. Nevertheless, the results open a not yet tested possibility that sulfide could be used per se and in combination with antibiotics as antimicrobials against drug resistance of non-sulfide producing pathogens.

\section{5. $\mathrm{H}_{2} \mathrm{~S}$ in Host-Pathogen Interactions}

Several works indicate that upregulation of genes encoding bacterial enzymes involved in sulfide biogenesis is an important adaptive response of pathogens during the infection process. Host-generated sulfide seems to modulate the course of bacterial and viral infections as $\mathrm{H}_{2} \mathrm{~S}$ activates macrophages and the phagolysosomal fusion process, resulting in significant enhancement of phagocytosis. Sulfide triggers induction of endogenous mammalian antioxidant defenses protecting cells from infection-associated oxidative stress $[36,37]$. It also inhibits the inflammatory response by suppressing the endotoxininduced tumor necrosis factor a $(\mathrm{TNF} \alpha)$ produced by macrophages [31,37-39].

Lipopolysaccharide (LPS), the cell wall component of Gram-negative bacteria that has inflammatory properties, stimulates sulfide production in human macrophages via NF- $K B$ /ERK [40]. In mouse models of septic shock, LPS raised the CSE expression in liver and kidney resulting in augmented levels of $\mathrm{H}_{2} \mathrm{~S}$ in tissues and serum [41,42]. In an animal model of sepsis, induced by Streptococcus pneumonia, infusion of NaHS reduced the sepsis-related lung, kidney injury and distant organ injury without apparent bacterial outgrowth [43].

Interestingly, it was reported that host-derived $\mathrm{H}_{2} \mathrm{~S}$ protects against viral infections, including COVID-19, by mechanisms that involved modulation of the NF-kB signaling [35,44-46].

In M. smegmatis viability in macrophages is enhanced in hosts with blocked transsulfuration pathway, while treatment with $N$-acetylcysteine, that augments the cysteine flux through the sulfide pathway, potentiate bacteria killing. A similar effect was observed in Mycoplasma fermentans infected macrophages, in which the mammalian cells derived sulfide reduces the inflammatory response through a mechanism that involves inhibition of NF- $\mathrm{kB}$ activation and nuclear translocation, and consequent decrease of the transcription of pro-inflammatory genes and of pro-inflammatory cytokines production. In Mycoplasma infected macrophages, $\mathrm{H}_{2} \mathrm{~S}$ upregulated the $\mathrm{Nrf} 2 / \mathrm{HO}-1$ pathway activating downstream HO-1 and superoxide dismutase 1 (SOD1), thus reducing intracellular ROS levels [37,47-50].

On the contrary, an $M$. tuberculosis infected host that actively produces sulfide seems to have an aggravated course of the infection. Low concentrations of a slow sulfide releaser increased the levels of glycolytic and TCA cycle metabolic intermediates, and promoted oxygen respiration at the level of the cytochrome $b d$ quinol oxidase, altogether stimulating M. tuberculosis growth. In addition, a transcriptomic analysis revealed the upregulation of genes belonging to the DosR/S/T dormancy regulon, and CsoR and RicR copper regulons suggesting that sulfide triggers $M$. tuberculosis dormancy [51]. Additionally, M. tuberculosisinfected mice that produce $\mathrm{H}_{2} \mathrm{~S}$ exhibited an excessive innate immune response, with suppression of the adaptive immune response, decreased levels of cytokines, such as IL-1 $\beta$, IL-6, IL-9, IL-12, TNF- $\alpha$, IL-17, IFN- $\gamma$, and inhibition of the central carbon metabolism. Consistent with this, infected animals with no capacity to produce $\mathrm{H}_{2} \mathrm{~S}$ survived longer, had lower bacterial burden in the lungs, spleens, and livers, and impairment of the central carbon metabolism was not observed. Thus, the excessive amount of sulfide produced by $M$. tuberculosis-infected macrophages and the lower amounts of pro-inflammatory cytokines circulating in the animal promote Mycobacterium spp. growth, and consequently the exacerbation of the tuberculosis infection [34].

On the other hand, inhibition of sulfide producing enzymes in E. coli and S. aureus, chemically or by gene deletion, lowered the bacterial loads in leukocytes and macrophages. When compared with the wild type, the sulfide-deficient strains are less resistant in infected mice, with animals having lower bacterial burden and IL-6 levels in the spleen and plasma, respectively [52-54]. 
Hydrogen sulfide has been implicated in ulcerative colitis and to contribute to halitosis, both conditions related with hosts with proliferation of anaerobic bacteria such as SRB and periodontopathogenic bacteria, respectively $[52,54]$.

\section{CO Utilizing Bacteria}

Carbon monoxide is utilized by several bacteria as energy source, e.g., Rhodopseudomonas sp., Methanosarcina barkeri and Methanobacterium formicicum [55]. In the dark, Rhodospirillum rubrum uses $\mathrm{CO}-\mathrm{H}_{2}$ as an energy source, reaching growth rates of approximately $80 \%$ when compared with light-driven growth. Clostridium ljungdahlii and C. autoethanogenumis also use $\mathrm{CO}$ as a carbon source, producing ethanol in the process [56,57]. The CO oxidation systems are spread in the microbial world [55,58-60], and present in Carboxydothermus hydrogenoformans [61], Azotobacter vinelandii [62], Mycobacterium spp. [63], and in some sulfate reducing bacteria, including the thermophilic archaeon Archaeoglobus fulgidus in which $\mathrm{CO}$ is an electron donor for sulfate reduction. The $\mathrm{CO}$ tolerance of these strains is considered a beneficial alternative to biodesulfurisation processes [64-66].

Growth on $\mathrm{CO}$ is sustained by carbon monoxide dehydrogenase (CODH) enzymes that catalyze oxidation of $\mathrm{CO}$ to $\mathrm{CO}_{2}$, that is transformed into cellular carbon by reductive $\mathrm{CO}_{2}$ fixation pathways, such as the Calvin-Benson-Bassham cycle, the reverse tricarboxylic acid cycle, the 3-hydropropionate cycle or the Wood-Ljunddahl pathway [59]. The processes coupled to $\mathrm{CO}$ oxidation are oxygen respiration, hydrogenogenesis, sulfate or sulfur respiration and carbonate respiration [67]. In several bacteria, CODH enzymes are encoded by the cox operon that is composed of $\operatorname{coxS}, \operatorname{coxM}$ and $\operatorname{cox} L$ genes expressing an iron-sulfur protein, a flavin adenine dinucleotide-binding protein and a catalytic molybdenum cytosine dinucleotide-binding protein, respectively. In agreement, strains inactivated in CODH encoding genes cannot use $\mathrm{CO}$ as electron acceptor $[64,68]$.

Transcriptomics studies of CO-oxidizing bacteria in the presence of $\mathrm{CO}$ gas were done for A. fulgidus, Parageobacillus thermoglucosidasius, Calderihabitans maritimus and C. pertinax. The general trend was the upregulation of CODH encoding genes, and in P. thermoglucosidasius a transcriptional pattern related with transition from aerobic to anaerobic growth was observed [56,65-67].

\section{Bacterial Responses to Toxic CO}

$\mathrm{CO}$ produces no major effects on humans when inhaled at very low concentrations and/or for a short period of time. However, high doses and prolonged exposure may cause symptoms such as visual disturbances and seizures and, when in concentrations above 2000 ppm can induce coma or even death. In mammals, CO binds to hemoglobin, having approximately 250 times more affinity to the protein than oxygen, leading to the formation of carboxyhemoglobin and reducing the oxygen carrying capacity of the blood, causing tissue hypoxia $[8,69]$. High levels of $\mathrm{CO}$ in the blood is associated with aggravated asthma, cystic fibrosis, diabetes, cardiac disease and severe renal failure [70,71].

High concentrations of $\mathrm{CO}$ also have an inhibitory effect on bacteria, and $\mathrm{CO}$ gas and CO-releasing molecules (CORMs) show antimicrobial properties in the micromolar range of concentrations, as first reported for E. coli and S. aureus, grown under aerobic and anaerobic conditions [72], and later for several other pathogens [73]. CORMs are, in general, organometallic complexes that release $\mathrm{CO}$ intracellularly in a controlled and efficient way and reaching concentrations higher than $\mathrm{CO}$ gas, whose solubility is low $[69,74]$. CORMs are considered as non-toxic to eukaryotic cells and mice $[75,76]$. CORMs may have an additive effect when combined with other antibiotics as shown for Helicobacter pylori and P. aeruginosa. Furthermore, in H. pylori, CORMs contributed to overcoming antibiotic resistance of clinical isolates [77-79]. Exposure of E. coli and P. aeruginosa to CO releasers also prevented biofilm maturation and killing of bacteria within an established biofilm $[79,80]$. A summary of the currently available data on the antimicrobials properties of several CORMs tested against a wide range of pathogens is presented in Table 1. 
Table 1. CORMs used as antimicrobials.

\begin{tabular}{|c|c|c|c|c|}
\hline CORM & Organism & $\begin{array}{l}\text { Concentration } \\
(\mu \mathrm{M})\end{array}$ & Atmosphere & Observations \\
\hline \multirow[t]{11}{*}{ CORM-2 } & H. pylori [77] & $195-390$ & Microaerobic & $\begin{array}{l}\text { Parental strain (26695) and six } \\
\text { clinical isolates (5599, 5611, 5846, } \\
4597,4574 \text { and 5587) }\end{array}$ \\
\hline & E. coli ATCC 23716 [72] & 250 & $\begin{array}{l}\text { Anaerobic, } \\
\text { aerobic }\end{array}$ & - \\
\hline & E. coli MG1655 [76] & 350 & Microaerobic & - \\
\hline & E. coli MG1655 [81] & 500 & Aerobic & - \\
\hline & E. coli UPEC J96 [81] & 500 & Aerobic & - \\
\hline & E. coli ESBL 7 [81] & 500 & Aerobic & ESBL clinical isolate 7 \\
\hline & $\begin{array}{l}\text { E. coli ESBL 1, E. coli UPEC 2, } \\
\text { E. coli MG1655 TG1 [80] }\end{array}$ & 500 & Aerobic & $\begin{array}{l}\text { ESBL and non-producing (UPEC) } \\
\text { UPEC isolates }\end{array}$ \\
\hline & $\begin{array}{l}\text { E. coli } \text { ESBL7, } \\
\text { E. coli } \mathrm{UPEC} 2 \\
\text { E. coli } \mathrm{K} 12 \text { [82] }\end{array}$ & 500 & Aerobic & $\begin{array}{l}\text { ESBL-producing ESBL and } \\
\text { non-producing UPEC isolates }\end{array}$ \\
\hline & S. aureus NCTC8325 [72] & 250 & $\begin{array}{l}\text { Aerobic, } \\
\text { microaerobic }\end{array}$ & - \\
\hline & P. aeruginosa [83] & 10 & Aerobic & - \\
\hline & $\begin{array}{l}\text { P. aeruginosa } \\
\text { PAO1 biofilms [79] }\end{array}$ & $25-200$ & Microaerobic & Static growth wells \\
\hline \multirow[t]{6}{*}{ CORM-3 } & E. coli MG1655 [84] & 100 & Aerobic & $25 \%$ air saturation \\
\hline & E. coli ATCC 23716 [72] & $200-400$ & Anaerobic & - \\
\hline & E. coli MG1655 [85] & $\begin{array}{l}30-400 \\
100-200\end{array}$ & $\begin{array}{l}\text { Aerobic } \\
\text { Anaerobic }\end{array}$ & - \\
\hline & S. aureus NCTC8325 [72] & 400 & Microaerobic & - \\
\hline & $\begin{array}{l}\text { P. aeruginosa PAO1 ATCC } \\
15692[78,83]\end{array}$ & 10,500 & Aerobic & - \\
\hline & $\begin{array}{l}\text { S. typhimurium } \\
\text { ATCC } 14028 \text { s [86] }\end{array}$ & 150 & $\mathrm{n} / \mathrm{a}$ & - \\
\hline ALF850 & E. coli MG1655 [76] & 650 & Microaerobic & - \\
\hline \multirow[t]{3}{*}{ ALF021 } & E. coli K12 ATCC 23716 [72] & 200 & Anaerobic & \\
\hline & S. aureus NCTC 8325 [72] & 500 & Aerobic & \\
\hline & & 600 & Microaerobic & \\
\hline \multirow[t]{3}{*}{ TryptoCORM } & E. coli W3110 $[87,88]$ & 100 & Aerobic & With irradiation \\
\hline & N. gonorrhoeae MS11 [88] & 100 & $5 \% \mathrm{CO}_{2}$ & In the dark \\
\hline & S. aureus $8325-4$ [88] & 100 & Aerobic & With irradiation and in the dark \\
\hline \multirow{3}{*}{$\begin{array}{l}\text { PhotoCORM } \\
\text { USC-CN028-31 } \\
(\mathrm{Mn}(\mathrm{CO}) 3(\text { tpa-k3N)Br) }\end{array}$} & E. coli EC958 [89] & 350 & Aerobic & Pre-exposed to UV light \\
\hline & Avian pathogenic E. coli [90] & 2000 & Microaerobic & - \\
\hline & E. coli K12 MG1655 [91] & $250-500$ & Aerobic & $\begin{array}{l}\text { Glucose or succinate as carbon } \\
\text { source; Transient to severe } \\
\text { reduction of growth }\end{array}$ \\
\hline \multirow[t]{3}{*}[\mathrm{Mn}(\mathrm{CO})3(\mathrm{bpy})(\mathrm{mcz})]{$\mathrm{PF} 6$} & $\begin{array}{l}\text { S. aureus, S. epidermidis } \\
\text { E. faecium, }\end{array}$ & 1.25 & $\mathrm{n} / \mathrm{a}$ & - \\
\hline & L. major, & 1.8 & $\mathrm{n} / \mathrm{a}$ & - \\
\hline & T. brucei [92] & 0.4 & $\mathrm{n} / \mathrm{a}$ & - \\
\hline \multirow[t]{3}{*}[\mathrm{Mn}(\mathrm{CO})3(\mathrm{bpy})(\mathrm{ktz})]{$\mathrm{PF} 6$} & S. aureus, S. epidermidis, & 2.5 & $\mathrm{n} / \mathrm{a}$ & - \\
\hline & L. major, & 2 & $\mathrm{n} / \mathrm{a}$ & - \\
\hline & T. brucei [92] & 0.7 & $\mathrm{n} / \mathrm{a}$ & - \\
\hline \multirow[t]{4}{*}[\mathrm{Mn}(\mathrm{CO})3(\mathrm{bpy})(\mathrm{ctz})]{$\mathrm{PF} 6$} & S. aureus, S. epidermidis, & 0.6 & $\mathrm{n} / \mathrm{a}$ & - \\
\hline & E. faecium, E. faecalis & 2.5 & $\mathrm{n} / \mathrm{a}$ & - \\
\hline & L. major, & 2.2 & $\mathrm{n} / \mathrm{a}$ & - \\
\hline & T. brucei [92] & 0.5 & $\mathrm{n} / \mathrm{a}$ & - \\
\hline CORM-371 & P. aeruginosa [83] & 10 & Aerobic & - \\
\hline CORM-1 nonwoven & $\begin{array}{l}\text { S. aureus MRSA } \\
\text { (biofilms) [93] }\end{array}$ & $\begin{array}{l}<3 \mu \mathrm{mol} \mathrm{CO} / \mathrm{mg} \\
\text { nonwoven }\end{array}$ & $\mathrm{n} / \mathrm{a}$ & $\begin{array}{l}70 \% \text { inhibition after irradiation at } \\
405 \mathrm{~nm}\end{array}$ \\
\hline
\end{tabular}


Table 1. Cont.

\begin{tabular}{|c|c|c|c|c|}
\hline CORM & Organism & $\begin{array}{l}\text { Concentration } \\
(\mu \mathrm{M})\end{array}$ & Atmosphere & Observations \\
\hline EBOR-CORM-1 & P. aeruginosa [94] & 500 & Microaerobic & $\begin{array}{l}\text { Tested in planktonic and biofilms } \\
\text { of PAO1 }\end{array}$ \\
\hline CORM-401 & E. coli K12 [95] & 500 & $\mathrm{n} / \mathrm{a}$ & - \\
\hline \multirow[t]{3}{*}{ ALF062 } & E. coli ATCC 23716 [72] & 50 & $\begin{array}{l}\text { Aerobic, } \\
\text { anaerobic }\end{array}$ & - \\
\hline & E. coli MG1655 [76] & 450 & Microaerobic & - \\
\hline & S. aureus NCTC 8325 [72] & 50 & $\begin{array}{l}\text { Microaerobic, } \\
\text { aerobic }\end{array}$ & - \\
\hline ALF186 & E. coli MG1655 [76] & 2000 & Microaerobic & - \\
\hline CORM-A1 & P. aeruginosa [83] & $10-500$ & Aerobic & Bacteriostatic \\
\hline
\end{tabular}

Studies on the bactericidal mode of action of CO done in E. coli, P. aeruginosa, H. pylori and Campylobacter jejuni showed that $\mathrm{CO}$ decreases the respiratory rates due to the direct binding to terminal oxidases $[77,78,85,96]$. Moreover, bacterial cells treated with CORM contained high intracellular ROS level [97-99]. Still, CO also targets non-heme proteins, as inferred by the similar $\mathrm{CO}$ susceptibility of heme-deficient $(\triangle h e m A)$ and wild-type strains of E. coli [100]. A metabolomic study of E. coli treated with the CO releaser CORM-3 reported the impairment of glutamate synthesis and inactivation of iron-sulfur enzymes, such as aconitase and fumarase, causing intracellular glutamate deficiency and inhibition of the nitrogen and TCA cycles [101]. In strains of sulfate-reducing bacteria of the Desulfovibrio genus, high CO concentrations $(20-70 \% v / v)$ inactivated hydrogenase and superoxide dismutase enzymes, and stimulated formation of ROS [87-89]. CO interacts with proteins such as albumin, ferritin and lysozyme via a protein- $\mathrm{Ru}(\mathrm{II})-(\mathrm{CO})_{2}$ adduct. The formation of this complex accelerates the release of $\mathrm{CO}$ from CORM-3, suggesting that plasma proteins may control the pharmacokinetic properties of CORMs [102]. Moreover, CO maintains its bactericidal properties under anaerobic conditions, and the absence of oxygen may even increase its toxicity as shown for E. coli and S. aureus [72]. Thus, in addition to its direct ligation to iron, other intracellular $\mathrm{CO}$ targets remain to be identified due to the affinity tometal atoms, such as cobalt, nickel and copper $[103,104]$.

Bacteria rely on CO sensors and CO-dependent regulators to utilize or control intracellular CO levels, most of them heme-containing proteins (Figure 2). However, $\mathrm{CO}$ has the ability to displace histidine, cysteine and tyrosine residues that are coordinated to metals. Thus, in several proteins, the displacement by $\mathrm{CO}$ of the proximal ligand of heme iron histidine is the basis of sensor functioning [105].

One of the best studied CO-regulators is CooA that is a member of the FNR/CRP family of transcriptional regulators and is present in a wide variety of bacteria. CooA is a homodimeric protein that upon $\mathrm{CO}$ binding to the heme undergoes a conformational change that triggers DNA ligation to the coo promoter, regulating the CO oxidation system $[7,106]$.

Some bacteria contain another type of CO regulator, namely RcoM, that upon binding of $\mathrm{CO}$ to its heme moiety controls transcription of coo and cox genes $[107,108]$. CooA responds only to CO, but other heme-based CO sensors also bind oxygen, namely Sinorhizobium meliloti FixLJ, Acetobacter xylinum AxPDEA1, B. subtilis HemAT, and E. coli Dos [109-112].

In M. tuberculosis, the kinases DosS (also known as DevS) and DosT are linked to dormancy. At high concentrations, $\mathrm{CO}$ binds to their heme groups promoting autophosphorylation and the subsequent phosphorylation of the DosR dormancy regulator leads to induction of the dormancy operon $[113,114]$. 


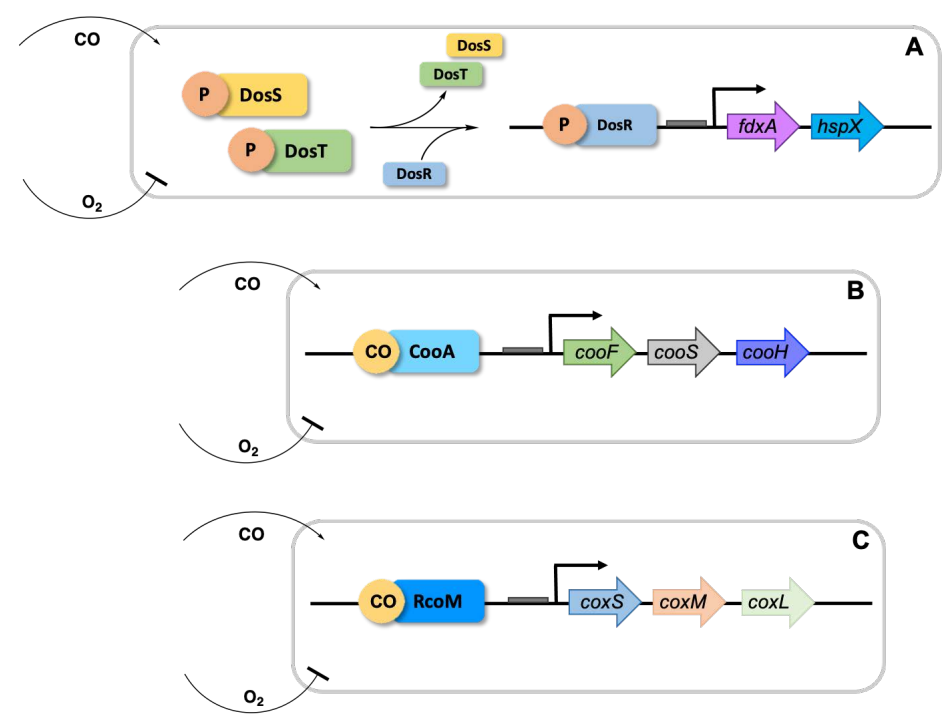

Figure 2. General scheme on the action of CO regulators. (A) Upregulation of the dormancy of DosR-phosphate transcriptional regulator is triggered by $\mathrm{CO}$ and $\mathrm{H}_{2} \mathrm{~S}$. (B,C) The CooA and RcoM regulators, which are activated by $\mathrm{CO}$, upregulate the transcription of the coo and cox gene products that catalyze conversion of $\mathrm{CO}$ to $\mathrm{CO}_{2}$.

Several works on the bacterial response to the stress imposed by $\mathrm{CO}$ and CORMs have been published. A transcriptomic study of E. coli exposed to $\mathrm{CO}$ gas revealed changes in the expression pattern of $\sim 30 \%$ of the whole genome [115]. In aerobic-grown E. coli cells, $\mathrm{CO}$ caused downregulation of several TCA cycle related genes, increase expression of $c y d A B$ encoding cytochrome $b d-I$, and upregulation of NADH dehydrogenase (ndh). Furthermore, $\mathrm{CO}$ mimicked anaerobic conditions as judged by the down-regulation of some of the ArcA regulated genes involved in the tricarboxylic acid cycle (TCA). These data were interpreted as resulting from the direct competition of $\mathrm{CO}$ for the oxygen binding sites of ArcA, which is a regulator that mediates the transcription of $\sim 11$ operons during an aerobic-anaerobic transition. $\mathrm{CO}$ gas also modified the expression of genes regulated by FNR, a major bacterial transcription factor that contains an [4Fe-4S] oxygen sensor cluster and represses over 100 genes, raising the possibility that it could be inactivated through $\mathrm{CO}$ binding to the iron-sulfur cluster. Additionally, the elevated expression of genes involved in arginine, taurine, and methionine biosynthesis, iron acquisition, and sulfur utilization/uptake, suggests that, in response to CO, cells undergo a shortage of amino acids, sulfur, and iron [115].

E. coli exposed to CO donors, such as CORM-2 and CORM-3 also caused major alteration of the mRNA abundance of a large number of genes $[100,116]$. In general, it resulted in the down-regulation of genes involved in the citric acid cycle and respiration (cyo $A B C D E$ and $s d h A B C D$ operon). However, small induction of the $c y d A B$ genes encoding cytochrome $b d$-I was observed, which is consistent with cytochrome $b d$-I being the more CO resistant oxidase [117]. Up-regulated genes were those participating in SOS response, DNA repair, protein homeostasis, zinc, methionine, sulfur and cysteine metabolism, and biofilm formation $[85,116]$. In general, the transcriptome alteration shared similarities with those observed for E. coli under oxidative stress (e.g., induction of members of the SoxRS regulon). Interestingly, in uropathogenic E. coli isolates, CORM-2 induced up-regulation of some virulence genes $[81,82]$.

\section{CO Producing Bacteria}

Several pathogens, like S. mitis and B. cereus, cause hemolysis during infection [118], and use heme-oxygenase enzymes to obtain iron from heme degradation. The first described bacterial heme oxygenase was $\mathrm{HmuO}$ of Corynebacterium diphtheriae. Over the years, several other heme oxygenases, regulated by intracellular iron concentration, have 
been found in pathogens, such as Cj1613c in C. jejuni, HugZ in H. pylori, and HemO in Neisseria meningitides [113,119-124].

Of note, some bacterial heme oxygenases release formaldehyde instead of $\mathrm{CO}$, as for example the S. aureus monooxygenases IsdG and IsdI, and M. tuberculosis MhuD [125]. In $S$. aureus, IsdG was proposed to link biosynthesis and uptake heme pathways, thus protecting the bacteria from intracellular heme toxic accumulation [126,127].

As mentioned above, endogenously produced sulfide appears to protect bacteria from a broad range of antibiotics. However, no similar effect was, so far, observed with $\mathrm{CO}$, since CO gas only marginally improved $E$. coli growth in the presence of the antibiotics such as doxycycline, trimethoprim or cefotaxime [115].

\section{9. $\mathrm{CO}$ and $\mathrm{H}_{2} \mathrm{~S}$ in Host-Pathogen Interactions}

The finding that HO-1 is highly induced in macrophages in response to bacterial infections, and that animals with blocked HO-1 were highly sensitive to bacteria and presented signs of systemic inflammatory response led to the proposal that $\mathrm{CO}$ enhances bacterial clearance [128]. In addition, HO-1-deficient mice showed increased bacteremia and lethality during sepsis, and their survival improved upon administration of $\mathrm{CO}$ donor molecules $[73,129]$. Moreover, Morse and colleagues reported that CO gas inhalation increased the survival of a sepsis mice model and reduced the levels of pro-inflammatory cytokines, and that overexpression of $\mathrm{HO}-1$ in macrophages caused decrease in the cytokine levels [130]. In another study, infections of the upper respiratory tract by the influenza virus elevated the amount of $\mathrm{CO}$ exhaled by patients, which was considered to be derived from the induction of heme oxygenase in macrophages and epithelial cells [123]. Pamplona et al. reported that inhalation of $\mathrm{CO}$ gas protected Plasmodium berghei infected mice from development of cerebral malaria, although it did not decrease parasitemia. Authors proposed that binding of $\mathrm{CO}$ to heme prevents the disruption of the blood-brain barrier and the consequent development of cerebral malaria associated to high toxic levels of free heme in erythrocytes derived from hemolysis [131,132].

However, some bacteria seem to be able profit from induction of host-derived CO production as a self-protection mechanism, as was shown for $M$. tuberculosis that induced HO-1 in infected macrophages with release of $\mathrm{CO}$ that triggers the dormant stage of M. tuberculosis [133].

\section{0. $\mathrm{H}_{2} \mathrm{~S}$ and $\mathrm{CO}$ Interplay}

The chemistry and biology of $\mathrm{H}_{2} \mathrm{~S}$ and $\mathrm{CO}$ are interconnected due to the shared capacity of these molecules to interact with metal centers and cysteine residues in proteins. Both molecules are involved in related signaling pathways, in which they promote activation/inactivation of the target proteins and may interfere in the level and activity of each other. For example, the $\mathrm{H}_{2} \mathrm{~S}$-generating CBS enzyme is reversibly inhibited by the $\mathrm{CO}$ derived from heme oxygenase, which is proposed to have pathophysiological implications including on the metabolism of cancer cells. Theregulatory heme-binding domain of the human CBS is absent from the homolog enzymes from prokaryotes or unicellular eukaryotes [134].

$\mathrm{H}_{2} \mathrm{~S}$ was reported to increase the expression of heme oxygenase, through the action of the Keap1/Nrf2 system on the HO-1 enzyme and because the intracellular sulfide levels seem to modulate the HO-2 activity through the several Cys-Pro signatures present in $\mathrm{HO}-2$ that regulate heme binding [135]. Moreover, $\mathrm{H}_{2} \mathrm{~S}$ is proposed to react with ferric verdoheme, an intermediate of the $\mathrm{HO}-2$ activity, thus modifying its oxygen-sensing activation mode [136]. Accordingly, $\mathrm{H}_{2} \mathrm{~S}$ was shown to upregulate the heme oxygenase in the pulmonary arteries of hypoxic rats and stimulate heme oxygenase levels in mouse retinal ganglion cells [137].

As mentioned above, both $\mathrm{CO}$ and $\mathrm{H}_{2} \mathrm{~S}$ deplete bacterial intracellular zinc levels and that in M. tuberculosis the two molecules induce the dormancy phase. Although several prokaryotes encode simultaneously in their genome enzymes that produce $\mathrm{CO}$ and $\mathrm{H}_{2} \mathrm{~S}$, 
the relationship between the function of the two molecules in bacterial physiology remains to be addressed.

\section{Conclusions}

Along with nitric oxide, $\mathrm{H}_{2} \mathrm{~S}$ and $\mathrm{CO}$ are double-edged molecules-if on the one hand are essential signaling molecules to human cells, on the other hand they can cause death This duplicity of function, which took decades to be recognized, is reminiscent of what also happens with metals. As with these, everything depends on the concentration, which when high is toxic but in small amounts is beneficial and even essential for the normal maintenance of organisms.

More recently, it has been shown that $\mathrm{CO}$ and $\mathrm{H}_{2} \mathrm{~S}$ can function as antimicrobials. There are already several examples of the effectiveness of CORMs as antimicrobials (Table 1), but similar studies remain to be done with $\mathrm{H}_{2} \mathrm{~S}$. In fact, sulfide and CO-based compounds may represent a novel kind of antimicrobials, with modes of action and targets that are different from those of the currently available antibiotics. And new antimicrobial drugs are urgently needed due to the growing number of infections caused by antibiotic-resistant pathogenic strains.

Author Contributions: Writing—original draft preparation, review and editing: S.S.M., V.M. and L.M.S. All authors have read and agreed to the published version of the manuscript.

Funding: This work was financially supported by Fundação para a Ciência e Tecnologia (Portugal) through fellowship PD/BD/148006/2019 (SSM), PTDC/SAU-INF/29313/2017 grant, and R\&D unit LISBOA-01-0145-FEDER007660 (MostMicro) cofounded by FCT/MCTES and FEDER funds under the PT2020 Partnership Agreement. This work was partially supported by PPBI-Portuguese Platform of BioImaging (PPBI-POCI-01-0145-FEDER-022122) co-funded by national funds from OE-“Orçamento de Estado" and by European funds from FEDER-“Fundo Europeu de Desenvolvimento Regional”. We also acknowledge funding from the European Union's Horizon 2020 research and innovation program under grant agreement No. 810856 .

Conflicts of Interest: The authors declare no conflict of interest.

\section{References}

1. Predmore, B.L.; Lefer, D.J.; Gojon, G. Hydrogen Sulfide in Biochemistry and Medicine. Antioxid. Redox Signal. 2012, 17, 119-140. [CrossRef]

2. Siracusa, R.; Schaufler, A.; Calabrese, V.; Fuller, P.M.; Otterbein, L.E. Carbon Monoxide: From Poison to Clinical Trials. Trends Pharmacol. Sci. 2021, 42, 329-339. [CrossRef]

3. Ereño-Orbea, J.; Majtan, T.; Oyenarte, I.; Kraus, J.P.; Martínez-Cruza, L.A. Structural Basis of Regulation and Oligomerization of Human Cystathionine $\beta$-Synthase, the Central Enzyme of Transsulfuration. Proc. Natl. Acad. Sci. USA 2013, 110. [CrossRef]

4. Zuhra, K.; Augsburger, F.; Majtan, T.; Szabo, C. Cystathionine- $\beta$-Synthase: Molecular Regulation and Pharmacological Inhibition. Biomolecules 2020, 10, 697. [CrossRef]

5. Szabo, C. Hydrogen Sulfide, an Endogenous Stimulator of Mitochondrial Function in Cancer Cells. Cells 2021, 10, 220. [CrossRef] [PubMed]

6. Gullotta, F.; di Masi, A.; Coletta, M.; Ascenzi, P. CO Metabolism, Sensing, and Signaling. BioFactors 2012, 38, 1-13. [CrossRef]

7. Gullotta, F.; Di Masi, A.; Ascenzi, P. Carbon Monoxide: An Unusual Drug. IUBMB Life 2012, 64, 378-386. [CrossRef]

8. Kourti, M.; Jiang, W.G.; Cai, J. Aspects of Carbon Monoxide in Form of CO-Releasing Molecules Used in Cancer Treatment: More Light on the Way. Oxid. Med. Cell. Longev. 2017, 2017. [CrossRef]

9. Ryter, S.W. Therapeutic Potential of Heme Oxygenase-1 and Carbon Monoxide in Acute Organ Injury, Critical Illness, and Inflammatory Disorders. Antioxidants 2020, 9, 1153. [CrossRef]

10. Ritter, J.M. Human Pharmacology of Hydrogen Sulfide, Putative Gaseous Mediator. Br. J. Clin. Pharmacol. 2010, 69, 573-575. [CrossRef] [PubMed]

11. Shatalin, K.; Shatalina, E.; Mironov, A.; Nudler, E. H2S: A Universal Defense Against Antibiotics in Bacteria. Science 2011, 334, 986-990. [CrossRef]

12. Li, Q.; Lancaster, J.R. Chemical Foundations of Hydrogen Sulfide Biology. Nitric Oxide Biol. Chem. 2013, 35, 21-34. [CrossRef]

13. Fu, L.H.; Wei, Z.Z.; Hu, K.D.; Hu, L.Y.; Li, Y.H.; Chen, X.Y.; Han, Z.; Yao, G.F.; Zhang, H. Hydrogen Sulfide Inhibits the Growth of Escherichia Coli through Oxidative Damage. J. Microbiol. 2018, 56, 238-245. [CrossRef] [PubMed]

14. Wu, G.; Wan, F.; Fu, H.; Li, N.; Gao, H. A Matter of Timing: Contrasting Effects of Hydrogen Sulfide on Oxidative Stress Response in Shewanella oneidensis. J. Bacteriol. 2015, 197, 3563-3572. [CrossRef] [PubMed] 
15. Fu, L.H.; Hu, K.D.; Hu, L.Y.; Li, Y.H.; Hu, L.B.; Yan, H.; Liu, Y.S.; Zhang, H. An Antifungal Role of Hydrogen Sulfide on the Postharvest Pathogens Aspergillus niger and Penicillium italicum. PLoS ONE 2014, 9. [CrossRef]

16. Ng, S.Y.; Ong, K.X.; Surendran, S.T.; Sinha, A.; Lai, J.J.H.; Chen, J.; Liang, J.; Tay, L.K.S.; Cui, L.; Loo, H.L.; et al. Hydrogen Sulfide Sensitizes Acinetobacter baumannii to Killing by Antibiotics. Front. Microbiol. 2020, 11, 1-9. [CrossRef]

17. Kolluru, G.K.; Shen, X.; Bir, S.C.; Kevil, C.G. Hydrogen Sulfide Chemical Biology: Pathophysiological Roles and Detection. Nitric Oxide Biol. Chem. 2013, 35, 5-20. [CrossRef]

18. Aroca, A.; Gotor, C.; Bassham, D.C.; Romero, L.C. Hydrogen Sulfide: From a Toxic Molecule to a Key Molecule of Cell Life. Antioxidants 2020, 9, 621. [CrossRef] [PubMed]

19. Avalos, M.; van Wezel, G.P.; Raaijmakers, J.M.; Garbeva, P. Healthy Scents: Microbial Volatiles as New Frontier in Antibiotic Research? Curr. Opin. Microbiol. 2018, 45, 84-91. [CrossRef]

20. Juarez, G.E.; Mateyca, C.; Galvan, E.M. Proteus Mirabilis Outcompetes Klebsiella pneumoniae in Artificial Urine Medium through Secretion of Ammonia and Other Volatile Compounds. Heliyon 2020, 6, e03361. [CrossRef]

21. Shimizu, T.; Masuda, S. Persulphide-Responsive Transcriptional Regulation and Metabolism in Bacteria. J. Infect. Dis. 2019, 220 , 125-132. [CrossRef]

22. Walsh, B.J.C.; Wang, J.; Edmonds, K.A.; Palmer, L.D.; Zhang, Y.; Trinidad, J.C.; Skaar, E.P.; Giedroc, D.P. The Response of Acinetobacter baumannii to Hydrogen Sulfide Reveals Two Independent Persulfide-Sensing Systems and a Connection to Biofilm Regulation. MBio 2020, 11, 1-18. [CrossRef]

23. Walsh, B.J.C.; Giedroc, D.P. $\mathrm{H}_{2}$ S and Reactive Sulfur Signaling at the Host-Bacterial Pathogen Interface. J. Biol. Chem. 2020, $295,13150-13168$. [CrossRef] [PubMed]

24. Forte, E.; Borisov, V.B.; Falabella, M.; Colaço, H.G.; Tinajero-Trejo, M.; Poole, R.K.; Vicente, J.B.; Sarti, P.; Giuffre, A. The Terminal Oxidase Cytochrome $b d$ Promotes Sulfide-Resistant Bacterial Respiration and Growth. Sci. Rep. 2016, 6, 23788. [CrossRef] [PubMed]

25. Tanous, C.; Soutourina, O.; Raynal, B.; Hullo, M.F.; Mervelet, P.; Gilles, A.M.; Noirot, P.; Danchin, A.; England, P.; Martin-Verstraete, I. The CymR Regulator in Complex with the Enzyme CysK Controls Cysteine Metabolism in Bacillus subtilis. J. Biol. Chem. 2008, 283, 35551-35560. [CrossRef]

26. Peng, H.; Zhang, Y.; Palmer, L.D.; Kehl-Fie, T.E.; Skaar, E.P.; Trinidad, J.C.; Giedroc, D.P. Hydrogen Sulfide and Reactive Sulfur Species Impact Proteome S-Sulfhydration and Global Virulence Regulation in Staphylococcus aureus. ACS Infect. Dis. 2017, 3, 744-755. [CrossRef]

27. Soutourina, O.; Poupel, O.; Coppée, J.Y.; Danchin, A.; Msadek, T.; Martin-Verstraete, I. CymR, the Master Regulator of Cysteine Metabolism in Staphylococcus aureus, Controls Host Sulphur Source Utilization and Plays a Role in Biofilm Formation. Mol. Microbiol. 2009, 73, 194-211. [CrossRef]

28. Shen, J.; Peng, H.; Zhang, Y.; Trinidad, J.C.; Giedroc, D.P. Staphylococcus aureus sqr Encodes a Type II Sulfide:Quinone Oxidoreductase and Impacts Reactive Sulfur Speciation in Cells. Biochemistry 2016, 55, 6524-6534. [CrossRef]

29. Luebke, J.L.; Shen, J.; Bruce, K.E.; Kehl-Fie, T.E.; Peng, H.; Skaar, E.P.; Giedroc, D.P. The CsoR-like Sulfurtransferase Repressor (CstR) Is a Persulfide Sensor in Staphylococcus aureus. Mol. Microbiol. 2014, 94, 1343-1360. [CrossRef]

30. Peng, H.; Shen, J.; Edmonds, K.A.; Luebke, J.L.; Hickey, A.K.; Palmer, L.D.; Chang, F.-M.J.; Bruce, K.A.; Kehl-Fie, T.E.; Skaar, E.P.; et al. Sulfide Homeostasis and Nitroxyl Intersect via Formation of Reactive Sulfur Species in Staphylococcus aureus. mSphere 2017, 2, 1-21. [CrossRef] [PubMed]

31. Weikum, J.; Ritzmann, N.; Jelden, N.; Klockner, A.; Herkersdorf, S.; Josten, M.; Sahl, H.-G.; Grein, F. Sulfide Protects Staphylococcus aureus from Aminoglycoside Antibiotics but Cannot Be Regarded as a General Defense Mechanism against Antibiotics. Antimicrob. Agents Chemother. 2018, 62, 1-10. [CrossRef]

32. Mironov, A.; Seregina, T.; Nagornykh, M.; Luhachack, L.G.; Korolkova, N.; Lopes, L.E.; Kotova, V.; Zavilgelsky, G.; Shakulov, R.; Shatalin, K.; et al. Mechanism of $\mathrm{H}_{2} \mathrm{~S}-$ Mediated Protection against Oxidative Stress in Escherichia coli. Proc. Natl. Acad. Sci. USA 2017, 114, 6022-6027. [CrossRef] [PubMed]

33. Ono, K.; Kitamura, Y.; Zhang, T.; Tsutsuki, H.; Rahman, A.; Ihara, T.; Akaike, T.; Sawa, T. Cysteine Hydropersulfide Inactivates $\beta$-Lactam Antibiotics with Formation of Ring-Opened Carbothioic S-Acids in Bacteria. ACS Chem. Biol. 2021, 16, 731-739. [CrossRef] [PubMed]

34. Rahman, M.A.; Glasgow, J.N.; Nadeem, S.; Reddy, V.P.; Sevalkar, R.R.; Lancaster, J.R.; Steyn, A.J.C. The Role of Host-Generated $\mathrm{H}_{2} \mathrm{~S}$ in Microbial Pathogenesis: New Perspectives on Tuberculosis. Front. Cell. Infect. Microbiol. 2020, 10, 586923. [CrossRef]

35. Pal, V.K.; Bandyopadhyay, P.; Singh, A. Hydrogen Sulfide in Physiology and Pathogenesis of Bacteria and Viruses. IUBMB Life 2018, 70, 393-410. [CrossRef] [PubMed]

36. Xie, Z.Z.; Liu, Y.; Bian, J.S. Hydrogen Sulfide and Cellular Redox Homeostasis. Oxid. Med. Cell. Longev. 2016, 2016. [CrossRef]

37. Benedetti, F.; Curreli, S.; Krishnan, S.; Davinelli, S.; Cocchi, F.; Scapagnini, G.; Gallo, R.C.; Zella, D. Anti-Inflammatory Effects of $\mathrm{H}_{2} \mathrm{~S}$ during Acute Bacterial Infection: A Review. J. Transl. Med. 2017, 15, 1-11. [CrossRef] [PubMed]

38. Sun, F.; Luo, J.H.; Yue, T.T.; Wang, F.X.; Yang, C.L.; Zhang, S.; Wang, X.Q.; Wang, C.Y. The Role of Hydrogen Sulphide Signalling in Macrophage Activation. Immunology 2021, 162, 3-10. [CrossRef]

39. Wallace, J.L.; Ferraz, J.G.P.; Muscara, M.N. Hydrogen Sulfide: An Endogenous Mediator of Resolution of Inflammation and Injury. Antioxid. Redox Signal. 2012, 17, 58-67. [CrossRef] 
40. Rivers-Auty, J. An Evolutionary Perspective on the Immunomodulatory Role of Hydrogen Sulphide. Med. Hypotheses 2015, 85, 612-617. [CrossRef]

41. Li, L.; Bhatia, M.; Zhu, Y.Z.; Zhu, Y.C.; Ramnath, R.D.; Wang, Z.J.; Anuar, F.B.M.; Whiteman, M.; Salto-Tellez, M.; Moore, P.K. Hydrogen Sulfide Is a Novel Mediator of Lipopolysaccharide-induced Inflammation in the Mouse. FASEB J. 2005, 19, $1196-1198$. [CrossRef]

42. Whiteman, M.; Li, L.; Rose, P.; Tan, C.H.; Parkinson, D.B.; Moore, P.K. The Effect of Hydrogen Sulfide Donors on LipopolysaccharideInduced Formation of Inflammatory Mediators in Macrophages. Antioxid. Redox Signal. 2010, 12, 1147-1154. [CrossRef]

43. Aslami, H.; Pulskens, W.P.; Kuipers, M.T.; Bos, A.P.; van Kuilenburg, A.B.P.; Wanders, R.J.A.; Roelofsen, J.; Roelofs, J.J.T.H.; Kerindongo, R.P.; Beurskens, C.J.P.; et al. Hydrogen Sulfide Donor NaHS Reduces Organ Injury in a Rat Model of Pneumococcal pneumosepsis, Associated with Improved Bio-Energetic Status. PLoS ONE 2013, 8. [CrossRef]

44. Bazhanov, N.; Ansar, M.; Ivanciuc, T.; Garofalo, R.P.; Casola, A. Hydrogen Sulfide: A Novel Player in Airway Development, Pathophysiology of Respiratory Diseases, and Antiviral Defenses. Am. J. Respir. Cell Mol. Biol. 2017, 57, 403-410. [CrossRef]

45. Citi, V.; Martelli, A.; Brancaleone, V.; Brogi, S.; Gojon, G.; Montanaro, R.; Morales, G.; Testai, L.; Calderone, V. Anti-Inflammatory and Antiviral Roles of Hydrogen Sulfide: Rationale for Considering $\mathrm{H}_{2}$ S Donors in COVID-19 Therapy. Br. J. Pharmacol. 2020, 177, $4931-4941$. [CrossRef] [PubMed]

46. Yang, G. MINI-REVIEW $\mathrm{H}_{2} \mathrm{~S}$ as a Potential Defense against COVID-19? J Physiol Cell Physiol 2020, 319, 244-249. [CrossRef] [PubMed]

47. Garg, S.; Vitvitsky, V.; Gendelman, H.E.; Banerjee, R. Monocyte Differentiation, Activation, and Mycobacterial Killing Are Linked to Transsulfuration-Dependent Redox Metabolism. J. Biol. Chem. 2006, 281, 38712-38720. [CrossRef]

48. Benedetti, F.; Davinelli, S.; Krishnan, S.; Gallo, R.C.; Scapagnini, G.; Zella, D.; Curreli, S. Sulfur Compounds Block MCP1 Production by Mycoplasma Fermentans-Infected Macrophages through NF-kB Inhibition. J. Transl. Med. 2014, 12, 1-11. [CrossRef]

49. Gemici, B.; Wallace, J.L. Anti-Inflammatory and Cytoprotective Properties of Hydrogen Sulfide. Methods Enzymol. 2015, 555, 169-193. [CrossRef]

50. Sen, N.; Paul, B.D.; Gadalla, M.M.; Mustafa, A.K.; Sen, T.; Xu, R.; Kim, S.; Snyder, S.H. Hydrogen Sulfide-Linked Sulfhydration of NF-кB Mediates Its Antiapoptotic Actions. Mol. Cell 2012, 45, 13-24. [CrossRef] [PubMed]

51. Saini, V.; Chinta, K.C.; Reddy, V.P.; Glasgow, J.N.; Stein, A.; Lamprecht, D.A.; Rahman, M.A.; Mackenzie, J.S.; Truebody, B.E.; Adamson, J.H.; et al. Hydrogen Sulfide Stimulates Mycobacterium tuberculosis Respiration, Growth and Pathogenesis. Nat. Commun. 2020, 11, 1-17. [CrossRef]

52. Rowan, F.E.; Docherty, N.G.; Coffey, J.C.; O'Connell, P.R. Sulphate-Reducing Bacteria and Hydrogen Sulphide in the Aetiology of Ulcerative Colitis. Br. J. Surg. 2009, 96, 151-158. [CrossRef] [PubMed]

53. Toliver-kinsky, T.; Cui, W.; Lee, S.; Shatalin, K.; Nudler, E.; Szabo, C. H2S, a Bacterial Defense Mechanism against the Host Immune Response. Infect. Immun. 2018, 87, 1-11. [CrossRef]

54. Hampelska, K.; Jaworska, M.M.; Babalska, Z.Ł.; Karpiński, T.M. The Role of Oral Microbiota in Intra-Oral Halitosis. J. Clin. Med. 2020, 9, 2484. [CrossRef]

55. Diender, M.; Stams, A.J.M.; Sousa, D.Z. Pathways and Bioenergetics of Anaerobic Carbon Monoxide Fermentation. Front. Microbiol. 2015, 6, 1275. [CrossRef] [PubMed]

56. Liu, Z.Y.; Jia, D.C.; Zhang, K.D.; Zhu, H.F.; Zhang, Q.; Jiang, W.H.; Gu, Y.; Li, F.L. Erratum for Liu et al., “Ethanol Metabolism Dynamics in Clostridium ljungdahlii Grown on Carbon Monoxide.". Appl. Environ. Microbiol. 2020, 86, 2376. [CrossRef]

57. Abrini, J.; Naveau, H.; Nyns, E.J. Clostridium autoethanogenum, sp. Nov., an Anaerobic Bacterium That Produces Ethanol from Carbon Monoxide. Arch. Microbiol. 1994, 161, 345-351. [CrossRef]

58. Robb, F.T.; Techtmann, S.M. Life on the Fringe: Microbial Adaptation to Growth on Carbon Monoxide. F1000Research 2018, 7, 1981. [CrossRef]

59. Ragsdale, S.W. Life with Carbon Monoxide. Crit. Rev. Biochem. Mol. Biol. 2004, 39, 165-195. [CrossRef]

60. Fukuyama, Y.; Inoue, M.; Omae, K.; Yoshida, T.; Sako, Y. Anaerobic and Hydrogenogenic Carbon Monoxide-Oxidizing Prokaryotes: Versatile Microbial Conversion of a Toxic Gas into an Available Energy, 1st ed.; Elsevier Inc.: Amsterdam, The Netherlands, 2020; Volume 110, ISBN 9780128207031.

61. Svetlitchnyi, V.; Peschel, C.; Acker, G.; Meyer, O. Two Membrane-Associated NiFeS-Carbon Monoxide Dehydrogenases from the Anaerobic Carbon-Monoxide-Utilizing Eubacterium Carboxydothermus hydrogenoformans. J. Bacteriol. 2001, 183, 5134-5144. [CrossRef] [PubMed]

62. Youn, H.; Kerby, R.L.; Conrad, M.; Roberts, G.P. Functionally Critical Elements of CooA-Related CO Sensors. J. Bacteriol. 2004, 186, 1320-1329. [CrossRef] [PubMed]

63. Kim, Y.M.; Park, S.W. Microbiology and Genetics of CO Utilization in Mycobacteria. Antonie Van Leeuwenhoek 2012, 101, 685-700. [CrossRef] [PubMed]

64. King, G.M.; Weber, C.F. Distribution, Diversity and Ecology of Aerobic CO-Oxidizing Bacteria. Nat. Rev. Microbiol. 2007, 5, 107-118. [CrossRef] [PubMed]

65. Henstra, A.M.; Dijkema, C.; Stams, A.J.M. Archaeoglobus fulgidus Couples CO Oxidation to Sulfate Reduction and Acetogenesis with Transient Formate Accumulation. Environ. Microbiol. 2007, 9, 1836-1841. [CrossRef] 
66. Plugge, C.M.; Sousa, J.A.B.; Christel, S.; Dopson, M.; Bijmans, M.F.M.; Stams, A.J.M.; Diender, M. Syngas as Electron Donor for Sulfate and Thiosulfate Reducing Haloalkaliphilic Microorganisms in a Gas-Lift Bioreactor. Microorganisms 2020, 8, 1451. [CrossRef]

67. Oelgeschläger, E.; Rother, M. Carbon Monoxide-Dependent Energy Metabolism in Anaerobic Bacteria and Archaea. Arch. Microbiol. 2008, 190, 257-269. [CrossRef]

68. Wilson, J.L.; Jesse, H.E.; Poole, R.K.; Davidge, K.S. Antibacterial Effects of Carbon Monoxide. Curr. Pharm. Biotechnol. 2012, 13, 760-768. [CrossRef]

69. Romão, C.C.; Blättler, W.A.; Seixas, J.D.; Bernardes, G.J.L. Developing Drug Molecules for Therapy with Carbon Monoxide. Chem. Soc. Rev. 2012, 41, 3571-3583. [CrossRef]

70. Zegdi, R.; Perrin, D.; Burdin, M.; Boiteau, R.; Tenaillon, A. Increased Endogenous Carbon Monoxide Production in Severe Sepsis. Intensive Care Med. 2002, 28, 793-796. [CrossRef]

71. Foresti, R.; Bani-Hani, M.G.; Motterlini, R. Use of Carbon Monoxide as a Therapeutic Agent: Promises and Challenges. Intensive Care Med. 2008, 34, 649-658. [CrossRef]

72. Nobre, L.S.; Seixas, J.D.; Romão, C.C.; Saraiva, L.M. Antimicrobial Action of Carbon Monoxide-Releasing Compounds. Antimicrob. Agents Chemother. 2007, 51, 4303-4307. [CrossRef] [PubMed]

73. Chin, B.Y.; Otterbein, L.E. Carbon Monoxide Is a Poison... to Microbes! CO as a Bactericidal Molecule. Curr. Opin. Pharmacol. 2009, 9, 490-500. [CrossRef] [PubMed]

74. Chaves-Ferreira, M.; Albuquerque, I.S.; Matak-Vinkovic, D.; Coelho, A.C.; Carvalho, S.M.; Saraiva, L.M.; Romão, C.C.; Bernardes, G.J.L. Spontaneous CO Release from $\mathrm{Ru}^{\mathrm{II}}(\mathrm{CO})_{2}$-Protein Complexes in Aqueous Solution, Cells, and Mice. Angeww. Chemie Int. Ed. 2015, 54, 1172-1175. [CrossRef]

75. Motterlini, R.; Mann, B.E.; Foresti, R. Therapeutic Applications of Carbon Monoxide-Releasing Molecules. Expert Opin. Investig. Drugs 2005, 14, 1305-1318. [CrossRef] [PubMed]

76. Nobre, L.S.; Jeremias, H.; Romão, C.C.; Saraiva, L.M. Examining the Antimicrobial Activity and Toxicity to Animal Cells of Different Types of CO-Releasing Molecules. Dalt. Trans. 2016, 45, 1455-1466. [CrossRef]

77. Tavares, A.F.; Parente, M.R.; Justino, M.C.; Oleastro, M.; Nobre, L.S.; Saraiva, L.M. The Bactericidal Activity of Carbon MonoxideReleasing Molecules against Helicobacter Pylori. PLoS ONE 2013, 8. [CrossRef]

78. Desmard, M.; Davidge, K.S.; Bouvet, O.; Morin, D.; Roux, D.; Foresti, R.; Ricard, J.D.; Denamur, E.; Poole, R.K.; Montravers, P.; et al. A Carbon Monoxide-releasing Molecule (CORM-3) Exerts Bactericidal Activity against Pseudomonas aeruginosa and Improves Survival in an Animal Model of Bacteraemia. FASEB J. 2009, 23, 1023-1031. [CrossRef] [PubMed]

79. Murray, T.S.; Okegbe, C.; Gao, Y.; Kazmierczak, B.I.; Motterlini, R.; Dietrich, L.E.P.; Bruscia, E.M. The Carbon Monoxide Releasing Molecule CORM-2 Attenuates Pseudomonas aeruginosa Biofilm Formation. PLoS ONE 2012, 7, e35499. [CrossRef]

80. Sahlberg Bang, C.; Kruse, R.; Johansson, K.; Persson, K. Carbon Monoxide Releasing Molecule-2 (CORM-2) Inhibits Growth of Multidrug-Resistant Uropathogenic Escherichia coli in Biofilm and Following Host Cell Colonization. BMC Microbiol. 2016, 16, 64. [CrossRef] [PubMed]

81. Bang, C.S.; Kruse, R.; Demirel, I.; Önnberg, A.; Söderquist, B.; Persson, K. Multiresistant Uropathogenic Extended-Spectrum $\beta$-Lactamase (ESBL)-Producing Escherichia coli Are Susceptible to the Carbon Monoxide Releasing Molecule-2 (CORM-2). Microb. Pathog. 2014, 66, 29-35. [CrossRef]

82. Bang, C.S.; Demirel, I.; Kruse, R.; Persson, K. Global Gene Expression Profiling and Antibiotic Susceptibility after Repeated Exposure to the Carbon Monoxide-Releasing Molecule-2 (CORM-2) in Multidrug-Resistant ESBL-Producing Uropathogenic Escherichia coli. PLoS ONE 2017, 12, e0178541. [CrossRef]

83. Desmard, M.; Foresti, R.; Morin, D.; Dagoussat, M.; Berdeaux, A.; Denamur, E.; Crook, S.H.; Mann, B.E.; Scapens, D.; Montravers, P.; et al. Differential Antibacterial Activity against Pseudomonas aeruginosa by Carbon Monoxide-Releasing Molecules. Antioxid. Redox Signal. 2012, 16, 153-163. [CrossRef] [PubMed]

84. Wilson, J.L.; Jesse, H.E.; Hughes, B.; Lund, V.; Naylor, K.; Davidge, K.S.; Cook, G.M.; Mann, B.E.; Poole, R.K. Ru(CO) 3 Cl(Glycinate) (CORM-3): A Carbon Monoxide-Releasing Molecule with Broad-Spectrum Antimicrobial and Photosensitive Activities against Respiration and Cation Transport in Escherichia coli. Antioxid. Redox Signal. 2013, 19, 497-509. [CrossRef]

85. Davidge, K.S.; Sanguinetti, G.; Yee, C.H.; Cox, A.G.; McLeod, C.W.; Monk, C.E.; Mann, B.E.; Motterlini, R.; Poole, R.K. Carbon MonoxideReleasing Antibacterial Molecules Target Respiration and Global Transcriptional Regulators. J. Biol. Chem. 2009, 284, $4516-4524$. [CrossRef] [PubMed]

86. Rana, N.; McLean, S.; Mann, B.E.; Poole, R.K. Interaction of the Carbon Monoxide-Releasing $\mathrm{Molecule} \mathrm{Ru}(\mathrm{CO})_{3} \mathrm{Cl}(\mathrm{glycinate})$ (CORM-3) with Salmonella enterica Serovar Typhimurium: In Situ Measurements of Carbon Monoxide Binding by Integrating Cavity Dual-Beam Spectrophotometry. Microbiology 2014, 160, 2771-2779. [CrossRef]

87. Ward, J.S.; Lynam, J.M.; Moir, J.; Fairlamb, I.J.S. Visible-Light-Induced CO Release from a Therapeutically Viable TryptophanDerived manganese(I) Carbonyl (TryptoCORM) Exhibiting Potent Inhibition against E. coli. Chem. A Eur. J. 2014, 20, 15061-15068. [CrossRef]

88. Ward, J.S.; Morgan, R.; Lynam, J.M.; Fairlamb, I.J.S.; Moir, J.W.B. Toxicity of Tryptophan Manganese(I) Carbonyl (Trypto-CORM), against Neisseria Gonorrhoeae. Medchemcomm 2017, 8, 346-352. [CrossRef] [PubMed] 
89. Tinajero-Trejo, M.; Rana, N.; Nagel, C.; Jesse, H.E.; Smith, T.W.; Wareham, L.K.; Hippler, M.; Schatzschneider, U.; Poole, R.K. Antimicrobial Activity of the Manganese Photoactivated Carbon Monoxide-Releasing Molecule $\left[\mathrm{Mn}(\mathrm{CO})_{3}\left(\mathrm{tpa}-\mathrm{K}_{3} \mathrm{~N}\right)\right]^{+}$Against a Pathogenic Escherichia coli That Causes Urinary Infections. Antioxid. Redox Signal. 2016, 24, 765-780. [CrossRef]

90. Betts, J.; Nagel, C.; Schatzschneider, U.; Poole, R.; La Ragione, R.M. Antimicrobial Activity of Carbon Monoxide-Releasing Molecule $\left[\mathrm{Mn}(\mathrm{CO})_{3}\left(\mathrm{tpa}_{-} \mathrm{K}_{3} \mathrm{~N}\right)\right] \mathrm{Br}$ versus Multidrug-Resistant Isolates of Avian Pathogenic Escherichia coli and Its Synergy with Colistin. PLoS ONE 2017, 12, e0186359. [CrossRef]

91. Nagel, C.; McLean, S.; Poole, R.K.; Braunschweig, H.; Kramer, T.; Schatzschneider, U. Introducing $\left[\mathrm{Mn}(\mathrm{CO})_{3}\left(\mathrm{tpa}-\mathrm{K}_{3} \mathrm{~N}\right)\right]^{+}$as a Novel Photoactivatable CO-Releasing Molecule with Well-Defined iCORM Intermediates-Synthesis, Spectroscopy, and Antibacterial Activity. Dalt. Trans. 2014, 43, 9986-9997. [CrossRef] [PubMed]

92. Simpson, P.V.; Nagel, C.; Bruhn, H.; Schatzschneider, U. Antibacterial and Antiparasitic Activity of Manganese(I) Tricarbonyl Complexes with Ketoconazole, Miconazole, and Clotrimazole Ligands. Organometallics 2015, 34, 3809-3815. [CrossRef]

93. Klinger-Strobel, M.; Gläser, S.; Makarewicz, O.; Wyrwa, R.; Weisser, J.; Pletz, M.W.; Schiller, A. Bactericidal Effect of a Photoresponsive Carbon Monoxide-Releasing Nonwoven against Staphylococcus aureus Biofilms. Antimicrob. Agents Chemother. 2016, 60, 4037-4046. [CrossRef]

94. Flanagan, L.; Steen, R.R.; Saxby, K.; Klatter, M.; Aucott, B.J.; Winstanley, C.; Fairlamb, I.J.S.; Lynam, J.M.; Parkin, A.; Friman, V.P. The Antimicrobial Activity of a Carbon Monoxide Releasing Molecule (EBOR-CORM-1) Is Shaped by Intraspecific Variation within Pseudomonas aeruginosa Populations. Front. Microbiol. 2018, 9, 195. [CrossRef]

95. Kaczara, P.; Motterlini, R.; Rosen, G.M.; Augustynek, B.; Bednarczyk, P.; Szewczyk, A.; Foresti, R.; Chlopicki, S. Carbon Monoxide Released by CORM-401 Uncouples Mitochondrial Respiration and Inhibits Glycolysis in Endothelial Cells: A Role for mitoBKCa Channels. Biochim. Biophys. Acta Bioenerg. 2015, 1847, 1297-1309. [CrossRef]

96. Smith, H.; Mann, B.E.; Motterlini, R.; Poole, R.K. The Carbon Monoxide-Releasing Molecule, $\mathrm{Corm}-3\left(\mathrm{Ru}(\mathrm{CO}){ }_{3} \mathrm{Cl}(\mathrm{Glycinate})\right.$ ), Targets Respiration and Oxidases in Campylobacter jejuni, Generating Hydrogen Peroxide. IUBMB Life 2011, 63, 363-371. [CrossRef]

97. Tavares, A.F.N.; Nobre, L.S.; Saraiva, L.M. A Role for Reactive Oxygen Species in the Antibacterial Properties of Carbon Monoxide-Releasing Molecules. FEMS Microbiol. Lett. 2012, 336, 1-10. [CrossRef]

98. Tavares, A.F.N.; Teixeira, M.; Romão, C.C.; Seixas, J.D.; Nobre, L.S.; Saraiva, L.M. Reactive Oxygen Species Mediate Bactericidal Killing Elicited by Carbon Monoxide-Releasing Molecules. J. Biol. Chem. 2011, 286, 26708-26717. [CrossRef] [PubMed]

99. Seixas, J.D.; Chaves-Ferreira, M.; Montes-Grajales, D.; Gonçalves, A.M.; Marques, A.R.; Saraiva, L.M.; Olivero-Verbel, J.; Romão, C.C.; Bernardes, G.J.L. An N-Acetyl Cysteine Ruthenium Tricarbonyl Conjugate Enables Simultaneous Release of CO and Ablation of Reactive Oxygen Species. Chem. A Eur. J. 2015, 21, 14708-14712. [CrossRef]

100. Wilson, J.L.; McLean, S.; Begg, R.; Sanguinetti, G.; Poole, R.K. Analysis of Transcript Changes in a Heme-Deficient Mutant of Escherichia coli in Response to CORM-3 [Ru(CO) ${ }_{3} \mathrm{Cl}($ glycinate)]. Genomics Data 2015, 5, 231-234. [CrossRef] [PubMed]

101. Carvalho, S.M.; Marques, J.; Romão, C.C.; Saraiva, L.M. Metabolomics of Escherichia coli Treated with the Antimicrobial Carbon Monoxide-Releasing Molecule CORM-3 Reveals Tricarboxylic Acid Cycle as Major Target. Antimicrob. Agents Chemother. 2019, 63, 1-18. [CrossRef]

102. Santos-Silva, T.; Mukhopadhyay, A.; Seixas, J.D.; Bernardes, G.J.; Romao, C.C.; Romao, M.J. Towards Improved Therapeutic CORMs: Understanding the Reactivity of CORM-3 with Proteins. Curr. Med. Chem. 2011, 18, 3361-3366. [CrossRef]

103. Kung, Y.; Doukov, T.I.; Seravalli, J.; Ragsdale, S.W.; Drennan, C.L. Crystallographic Snapshots of Cyanide- and Water-Bound CClusters from Bifunctional Carbon Monoxide Dehydrogenase/acetyl-CoA Synthase. Biochemistry 2009, 48, 7432-7440. [CrossRef]

104. Stripp, S.T.; Goldet, G.; Brandmayr, C.; Sanganas, O.; Vincent, K.A.; Haumann, M.; Armstrong, F.A.; Happe, T. How Oxygen Attacks [FeFe] Hydrogenases from Photosynthetic Organisms. Proc. Natl. Acad. Sci. USA 2009, 106, 17331-17336. [CrossRef]

105. Tsai, A.L.; Martin, E.; Berka, V.; Olson, J.S. How Do Heme-Protein Sensors Exclude Oxygen? Lessons Learned from Cytochrome $\mathrm{c}^{\prime}$, Nostoc Puntiforme Heme Nitric Oxide/oxygen-Binding Domain, and Soluble Guanylyl Cyclase. Antioxid. Redox Signal. 2012, 17, 1246-1263. [CrossRef] [PubMed]

106. Roberts, G.P.; Youn, H.; Kerby, R.L. CO-Sensing Mechanisms. Microbiol. Mol. Biol. Rev. 2004, 68, 453-473. [CrossRef] [PubMed]

107. Salman, B.I.; Ali, M.F.B.; Marzouq, M.A.; Hussein, S.A. Utility of the Fluorogenic Characters of Benzofurazan for Analysis of Tigecycline Using Spectrometric Technique; Application to Pharmacokinetic Study, Urine and Pharmaceutical Formulations. Luminescence 2019, 34, 175-182. [CrossRef]

108. Kerby, R.L.; Youn, H.; Roberts, G.P. RcoM: A New Single-Component Transcriptional Regulator of CO Metabolism in Bacteria. J. Bacteriol. 2008, 190, 3336-3343. [CrossRef] [PubMed]

109. Gilles-Gonzalez, M.A.; Gonzalez, G.; Perutz, M.F.; Kiger, L.; Marden, M.C.; Poyart, C. Heme-Based Sensors, Exemplified by the Kinase FixL, Are a New Class of Heme Protein with Distinctive Ligand Binding and Autoxidation. Biochemistry 1994, 33, 8067-8073. [CrossRef]

110. Chang, A.L.; Tuckerman, J.R.; Gonzalez, G.; Mayer, R.; Weinhouse, H.; Volman, G.; Amikam, D.; Benziman, M.; Gilles-Gonzalez, M.A. Phosphodiesterase A1, a Regulator of Cellulose Synthesis in Acetobacter xylinum, Is a Heme-Based Sensor. Biochemistry 2001, 40, 3420-3426. [CrossRef]

111. Zhang, W.; Olson, J.S.; Phillips, G.N. Biophysical and Kinetic Characterization of HemAT, an Aerotaxis Receptor from Bacillus subtilis. Biophys. J. 2005, 88, 2801-2814. [CrossRef]

112. Delgado-Nixon, V.M.; Gonzalez, G.; Gilles-Gonzalez, M.A. Dos, a Heme-Binding PAS Protein from Escherichia coli, Is a Direct Oxygen Sensor. Biochemistry 2000, 39, 2685-2691. [CrossRef] [PubMed] 
113. Shiloh, M.U.; Manzanillo, P.; Cox, J.S. Mycobacterium tuberculosis Senses Host-Derived Carbon Monoxide during Macrophage Infection. Cell Host Microbe 2008, 3, 323-330. [CrossRef]

114. Sivaramakrishnan, S.; De Montellano, P.R.O. The DosS-DosT/DosR Mycobacterial Sensor System. Biosensors 2013 , 3, $259-282$. [CrossRef] [PubMed]

115. Wareham, L.K.; Begg, R.; Jesse, H.E.; Van Beilen, J.W.A.; Ali, S.; Svistunenko, D.; McLean, S.; Hellingwerf, K.J.; Sanguinetti, G.; Poole, R.K. Carbon Monoxide Gas Is Not Inert, but Global, in Its Consequences for Bacterial Gene Expression, Iron Acquisition, and Antibiotic Resistance. Antioxid. Redox Signal. 2016, 24, 1013-1028. [CrossRef]

116. Nobre, L.S.; Al-Shahrour, F.; Dopazo, J.; Saraiva, L.M. Exploring the Antimicrobial Action of a Carbon Monoxide-Releasing Compound through Whole-Genome Transcription Profiling of Escherichia coli. Microbiology 2009, 155, 813-824. [CrossRef]

117. Forte, E.; Borisov, V.B.; Siletsky, S.A.; Petrosino, M.; Giuffrè, A. In the Respiratory Chain of Escherichia coli Cytochromes bd-I and bd-II Are More Sensitive to Carbon Monoxide Inhibition than Cytochrome bo3. Biochim. Biophys. Acta Bioenerg. 2019, 1860, 148088. [CrossRef] [PubMed]

118. Kajimura, M.; Fukuda, R.; Bateman, R.M.; Yamamoto, T.; Suematsu, M. Interactions of Multiple Gas-Transducing Systems: Hallmarks and Uncertainties of CO, NO, and $\mathrm{H}_{2} \mathrm{~S}$ Gas Biology. Antioxid. Redox Signal. 2010, 13, 157-192. [CrossRef]

119. Pazicni, S.; Cherney, M.M.; Lukat-Rodgers, G.S.; Oliveriusová, J.; Rodgers, K.R.; Kraus, J.P.; Burstyn, J.N. The Heme of Cystathionine $\beta$-Synthase Likely Undergoes a Thermally Induced Redox-Mediated Ligand Switch. Biochemistry 2005, 44, 16785-16795. [CrossRef] [PubMed]

120. Hou, S.; Larsen, R.W.; Boudko, D.; Riley, C.W.; Karatan, E.; Zimmer, M.; Ordal, G.W.; Alam, M. Myoglobin-like Aerotaxis Transducers in Archaea and Bacteria. Nature 2000, 403, 540-544. [CrossRef]

121. Hirotsu, S.; Chu, G.C.; Unno, M.; Lee, D.S.; Yoshida, T.; Park, S.Y.; Shiro, Y.; Ikeda-Saito, M. The Crystal Structures of the Ferric and Ferrous Forms of the Heme Complex of HmuO, a Heme Oxygenase of Corynebacterium diphtheriae. J. Biol. Chem. 2004, 279 , 11937-11947. [CrossRef]

122. Ridley, K.A.; Rock, J.D.; Li, Y.; Ketley, J.M. Heme Utilization in Campylobacter jejuni. J. Bacteriol. 2006, 188, 7862-7875. [CrossRef]

123. Guo, Y.; Guo, G.; Mao, X.; Zhang, W.; Xiao, J.; Tong, W.; Liu, T.; Xiao, B.; Liu, X.; Feng, Y.; et al. Functional Identification of HugZ, a Heme Oxygenase from Helicobacter pylori. BMC Microbiol. 2008, 8. [CrossRef]

124. Zhu, W.; Wilks, A.; Stojiljkovic, I. Degradation of Heme in Gram-Negative Bacteria: The Product of the hemO Gene of Neisseriae Is a Heme Oxygenase. J. Bacteriol. 2000, 182, 6783-6790. [CrossRef]

125. Nambu, S.; Matsui, T.; Goulding, C.W.; Takahashi, S.; Ikeda-Saito, M. A New Way to Degrade Heme: The Mycobacterium tuberculosis Enzyme MhuD Catalyzes Heme Degradation without Generating CO. J. Biol. Chem. 2013, 288, 10101-10109. [CrossRef]

126. Matsui, T.; Nambu, S.; Ono, Y.; Goulding, C.W.; Tsumoto, K.; Ikeda-Saito, M. Heme Degradation by Staphylococcus aureus IsdG and IsdI Liberates Formaldehyde rather than Carbon Monoxide. Biochemistry 2013, 52, 3025-3027. [CrossRef] [PubMed]

127. Videira, M.A.M.; Lobo, S.A.L.; Silva, L.S.O.; Palmer, D.J.; Warren, M.J.; Prieto, M.; Coutinho, A.; Sousa, F.L.; Fernandes, F.; Saraiva, L.M. Staphylococcus aureus Haem Biosynthesis and Acquisition Pathways Are Linked through Haem Monooxygenase IsdG. Mol. Microbiol. 2018, 109, 385-400. [CrossRef] [PubMed]

128. Wegiel, B.; Larsen, R.; Gallo, D.; Chin, B.Y.; Harris, C.; Mannam, P.; Kaczmarek, E.; Lee, P.J.; Zuckerbraun, B.S.; Flavell, R.; et al. Macrophages Sense and Kill Bacteria through Carbon Monoxide-Dependent Inflammasome Activation. J. Clin. Investig. 2014, 124, 4926-4940. [CrossRef]

129. Su, W.C.; Liu, X.; Macias, A.A.; Baron, R.M.; Perrella, M.A. Heme Oxygenase-1-Derived Carbon Monoxide Enhances the Host Defense Response to Microbial Sepsis in Mice. J. Clin. Investig. 2008, 118, 239-247. [CrossRef]

130. Morse, D.; Pischke, S.E.; Zhou, Z.; Davis, R.J.; Flavell, R.A.; Loop, T.; Otterbein, S.L.; Otterbein, L.E.; Choi, A.M.K. Suppression of Inflammatory Cytokine Production by Carbon Monoxide Involves the JNK Pathway and AP-1. J. Biol. Chem. 2003, 278, 36993-36998. [CrossRef]

131. Jeney, V.; Ramos, S.; Bergman, M.L.; Bechmann, I.; Tischer, J.; Ferreira, A.; Oliveira-Marques, V.; Janse, C.J.; Rebelo, S.; Cardoso, S.; et al. Control of Disease Tolerance to Malaria by Nitric Oxide and Carbon Monoxide. Cell Rep. 2014, 8, 126-136. [CrossRef]

132. Pamplona, A.; Ferreira, A.; Balla, J.; Jeney, V.; Balla, G.; Epiphanio, S.; Chora, Â.; Rodrigues, C.D.; Gregoire, I.P.; Cunha-Rodrigues, M.; et al. Heme Oxygenase-1 and Carbon Monoxide Suppress the Pathogenesis of Experimental Cerebral Malaria. Nat. Med. 2007, 13, 703-710. [CrossRef] [PubMed]

133. Scharn, C.R.; Collins, A.C.; Nair, V.R.; Stamm, C.E.; Marciano, D.K.; Graviss, E.A.; Shiloh, M.U. Heme Oxygenase-1 Regulates Inflammation and Mycobacterial Survival in Human Macrophages during Mycobacterium tuberculosis Infection. J. Immunol. 2016, 196, 4641-4649. [CrossRef] [PubMed]

134. Giuffrè, A.; Vicente, J.B. Review Article Hydrogen Sulfide Biochemistry and Interplay with Other Gaseous. Oxid. Med. Cell. Longev. 2018, 2018, 31. [CrossRef]

135. Xie, L.; Gu, Y.; Wen, M.; Zhao, S.; Wang, W.; Ma, Y.; Meng, G.; Han, Y.; Wang, Y.; Liu, G.; et al. Hydrogen Sulfide Induces Keap1 S-Sulfhydration and Suppresses Diabetes-Accelerated Atherosclerosis via Nrf2 Activation. Diabetes 2016, 65, 3171-3184. [CrossRef] 
136. Matsui, T.; Sugiyama, R.; Sakanashi, K.; Tamura, Y.; Iida, M.; Nambu, Y.; Higuchi, T.; Suematsu, M.; Ikeda-Saito, M. Hydrogen Sulfide Bypasses the Rate-Limiting Oxygen Activation of Heme Oxygenase. J. Biol. Chem. 2018, 293, 16931-16939. [CrossRef] [PubMed]

137. Majid, A.S.A.; Majid, A.M.S.A.; Yin, Z.Q.; Ji, D. Slow Regulated Release of $\mathrm{H}_{2} \mathrm{~S}$ Inhibits Oxidative Stress Induced Cell Death by Influencing Certain Key Signaling Molecules. Neurochem. Res. 2013, 38, 1375-1393. [CrossRef] [PubMed] 